\title{
Who is Mark Myers?
}

That's what many US geologists are asking in the wake of an announcement that President George W. Bush will nominate Myers to head the US Geological Survey (USGS). The agency spends nearly $\$ 1$ billion each year on research, including earthquake monitoring, mapmaking and even biological studies.

Myers has a $\mathrm{PhD}$ in geology and has spent much of his career in Alaska, working for oil companies and for the state - sometimes alone in remote locations, armed with a shotgun in case of grizzly bears. "Never had to use it," he says. "I keep a clean camp." He served in the Air Force Reserve for 26 years, for a time in intelligence in Alaska's far north.

If confirmed by the Senate, Myers would be the first USGS director in decades to come neither from academia nor from within the agency. His history has made many academic geologists nervous, says Charles Groat, the agency's previous director. "The biggest question is, since he is so identified with oil and gas, what is his agenda?" says Groat, now at the University of Texas, Austin.

Myers worked most recently as head of Alaska's Division of Oil and Gas.

In the past he has supported drilling for oil and gas in the Arctic National Wildlife Refuge - a protected region of Alaska. And this has spooked some environmentalists. But if he gets the USGS job, Myers says, he would stay out of any decision making: "My job is strictly to provide the data, to help people understand the data and its limitations."

Last autumn, Myers resigned in protest after Alaska's governor dismissed Tom Irwin, then natural resources commissioner for

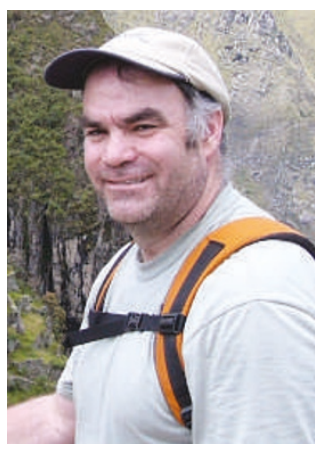

Mark Myers may soon head the US Geological Survey. director at the American Geological Institute in Alexandria, Virginia, says she is reassured by the incident: "If he's willing to resign from his very prominent position in Alaska, he's not really going to be political."

That is, of course, the big question. The Bush administration has a reputation for manipulating science to fit its ideology and goals. But Myers says that during his job interview with the White House personnel office, "one of the key things I was asked is: how do you maintain the objectivity of the science in a political environment? I was very encouraged by this question." He says the only politically directed question put the state. The dispute was over a natural-gas pipeline deal between Alaska and major oil companies. Linda Rowan, government affairs to him was: "Would you support the president?" - to which he said yes.

Emma Marris 